\title{
Formation of reproductive organs of young livestock depending on paratypic factors
}

\author{
Alexey Zelenkovi, 2,*, Galina Zelenkova ${ }^{2}$, Alexey Ermakov², Ivan Gorlov ${ }^{3}$, Sergei \\ Tresnitskii ${ }^{2}$, Natalieia Lesovaia ${ }^{2}$, Alexander Pakhomov ${ }^{4}$, Aleksandr Yenin $^{5}$ \\ ${ }^{1}$ Ministry of Agriculture and Food of the Rostov region, Krasnoarmeyskaya St., 33, Rostov-on-Don, \\ 344010, Russia \\ ${ }^{2}$ Don State Technical University, sq. Gagarina, 1, Rostov-on-Don, 344010, Russia \\ ${ }^{3}$ The Volga region research institute of manufacture and processing of meat-and-milk products, \\ Rokossovsky St., 6, Volgograd, 400131, Russia \\ ${ }^{4}$ Don State Agrarian University, o. Persianovsky, 346493, Russia \\ ${ }^{5}$ State educational institution of the LPR "Lugansk National Agrarian University", Lugansk, LPR
}

\begin{abstract}
The study was conducted to identify the early use of young animals (gobies and heifers) in cattle for breeding purposes. The condition under which the research was carried out was intensive and traditional rearing of young cattle. In the experimental groups, feeding was intense, and in the control groups - according to the accepted technology in the farm. Young growth was carried out until the age of 15 months. Under such different growing conditions, we have established the features of the formation of reproductive organs in gobies and heifers. The good development of the genitals of the heifers of the experimental group, and especially the ovaries, made it possible to carry out their fruitful insemination in the period from 13 to 14 months of age. For this, two bulls were selected from the experimental group at the age of 12-13 months, which, by manual mating, inseminated 20 heifers for a month. During a rectal examination, they turned out to be all pregnant and in due time, without complications, became hotels, gave normal viable offspring. Calving calves aged 22-23 months during 1 lactation they were in no way inferior in milk production to heifers inseminated at the age of 24-28 months and calving at 33-37 months.
\end{abstract}

\section{Introduction}

The profitability of cattle breeding depends on a variety of genetic parameters of livestock and paratypical factors influencing it. Also, success in leading the livestock industry depends on the reproduction of the herd by introducing high-quality young stock into the herd. Therefore, the sooner the heifers reach economic maturity, the faster will be the payback of the costs incurred for reproduction and rearing of young animals [1-9].

In order to identify its early use for breeding purposes, a study was carried out with intensive and traditional rearing of young cattle.

\footnotetext{
* Corresponding author: zelenkovalex@rambler.ru
} 


\section{Materials and methods}

The selected young red steppe breed was formed into 4 groups - 2 gobies (Ia - experience, $\mathrm{Ib}$ - control) and 2 heifers (IIa - experience and IIb - control), was kept indoors in the winter, and with the onset of heat was brought to the feeding grounds. The conditions of young animals $(\mathrm{n}=100)$ of all groups were identical. The area for 1 animal in the premises was $1.8 \mathrm{~m}^{2}$, in the feed yards $-10 \mathrm{~m}^{2}$. The front of feeding is $0.5 \mathrm{~m}$. Watering was carried out from group drinking bowls. Feeding in the winter was carried out indoors, and in the summer - on the feeding grounds.

\section{Results and discussion}

In the experimental groups, feeding was intense, and in the control groups - according to the accepted technology in the household (table 1).

Table 1. The amount of feed and their nutrition consumed by experimental young animals (per 1 animal).

\begin{tabular}{|c|c|c|c|c|c|c|c|c|}
\hline \multirow{3}{*}{ Stern } & \multicolumn{4}{|c|}{ Gobies $(\mathrm{n}=50)$} & \multicolumn{4}{|c|}{ Heifers $(n=50)$} \\
\hline & \multicolumn{2}{|c|}{ Ia } & \multicolumn{2}{|c|}{$\mathrm{Ib}$} & \multicolumn{2}{|c|}{ IIa } & \multicolumn{2}{|c|}{$\mathrm{IIb}$} \\
\hline & $\mathrm{kg}$ & $\begin{array}{l}\text { feed } \\
\text { units }\end{array}$ & $\mathrm{kg}$ & $\begin{array}{l}\text { feed } \\
\text { units }\end{array}$ & $\mathrm{kg}$ & $\begin{array}{l}\text { feed } \\
\text { units }\end{array}$ & $\mathrm{kg}$ & $\begin{array}{l}\text { feed } \\
\text { units }\end{array}$ \\
\hline \multicolumn{9}{|c|}{ From birth to 8 months of age } \\
\hline Compound feed & 355.8 & 355.8 & 205 & 205 & 311.7 & 311.7 & 205 & 205 \\
\hline Barley & 117.8 & 142.5 & 45.9 & 55.5 & 98.4 & 119.1 & 45.9 & 55.5 \\
\hline Corn Dirt & - & $\mathrm{x}$ & 37.8 & 42.3 & 28.8 & 32.3 & 37.8 & 42.3 \\
\hline Corn silo & 368.4 & 62.6 & 393.7 & 66.9 & 362.6 & 61.6 & 403.0 & 68.5 \\
\hline $\begin{array}{l}\text { Green mass of } \\
\text { herbs }\end{array}$ & 577.6 & 110.6 & 677.2 & 129.7 & 554.1 & 106.1 & 686.8 & 125.8 \\
\hline Alfalfa Hay & 40.4 & 19.8 & 49.6 & 24.3 & 40.4 & 19.8 & 49.6 & 24.3 \\
\hline $\begin{array}{l}\text { Total } \\
\text { including } \\
\text { concentrates }\end{array}$ & 473.6 & $\begin{array}{l}896.5 \\
498.3 \\
\end{array}$ & 288.7 & $\begin{array}{l}639.0 \\
302.8 \\
\end{array}$ & 438.9 & $\begin{array}{l}816.7 \\
463.1 \\
\end{array}$ & $\begin{array}{c}- \\
288.7 \\
\end{array}$ & $\begin{array}{l}636.7 \\
302.6 \\
\end{array}$ \\
\hline \multicolumn{9}{|c|}{ From birth to 15 months of age } \\
\hline Whole milk & 180.5 & 61.4 & 180.5 & 61.4 & 180.5 & 61.4 & 180.5 & 61.4 \\
\hline Reverse & 696.7 & 90.6 & 209.0 & 27.2 & 622.7 & 80.9 & 209.0 & 27.2 \\
\hline Compound feed & 1285.3 & 1285.3 & 563.5 & 563.5 & 1104.3 & 1104.3 & 564.7 & 564.7 \\
\hline Barley & 145.8 & 176.4 & 54.3 & 65.7 & 120.8 & 146.2 & 54.3 & 65.7 \\
\hline Corn Dirt & - & $\mathrm{x}$ & 223.8 & 228.3 & 28.8 & 32.2 & 190.8 & 195.3 \\
\hline Corn silo & 1775.9 & 301.9 & 1354.7 & 230.2 & 1785.5 & 303.6 & 1365.5 & 232.1 \\
\hline Cabbage & 24.0 & 2.4 & 52.0 & 5.2 & 21.0 & 2.4 & 52.0 & 5.2 \\
\hline $\begin{array}{l}\text { Green mass of } \\
\text { herbs }\end{array}$ & 877.6 & 164.0 & 977.2 & 183.1 & 854.1 & 159.5 & 957.1 & 179.1 \\
\hline Alfalfa Hay & 151.3 & 74.1 & 176.5 & 86.5 & 151.3 & 74.1 & 176.5 & 86.5 \\
\hline Sudanese hay & 149.2 & 77.6 & 175.0 & 91.0 & 158.1 & 82.2 & 171.7 & 83.3 \\
\hline Hay winter rye & 1.0 & 0.5 & 2.0 & 1.0 & 1.0 & 0.5 & 2.0 & 1.0 \\
\hline Corn straw & 3.2 & 0.6 & 617.6 & 123.5 & 2.6 & 0.5 & 608.6 & 121.7 \\
\hline Barley straw & 33.7 & 12.1 & 50.0 & 18.0 & 33.7 & 12.1 & 45.9 & 16.5 \\
\hline $\begin{array}{l}\text { Total } \\
\text { including } \\
\text { concentrates }\end{array}$ & $\begin{array}{c}- \\
1430.1\end{array}$ & $\begin{array}{l}2246.9 \\
1461.7 \\
\end{array}$ & $\begin{array}{c}- \\
841.6\end{array}$ & $\begin{array}{l}1684.6 \\
857.5 \\
\end{array}$ & $\begin{array}{c}- \\
1253.9\end{array}$ & $\begin{array}{l}2059.9 \\
1282.7 \\
\end{array}$ & $\begin{array}{c}- \\
809.8\end{array}$ & $\begin{array}{r}1645.7 \\
825.7 \\
\end{array}$ \\
\hline
\end{tabular}


Young growth was carried out until the age of 15 months. During this period, the bulls of group Ia consumed more feed at a total nutritional rate of 562.3 feed units. $(33.4 \%)$, concentrates - 604.2 feed. units (70.5\%) than the analogues of group IIb (table. 2). Accordingly, heifers of group IIa for 441.2 food. units (25.2\%) and 457 (55.4). The animals of the experimental groups consumed corn silage more, but less than the green mass of corn, hay, corn and barley straw. The calves of group Ia in the structure of the diet of concretes had $14.2 \%$ more than the control, and for heifers this difference was $12.2 \%$. Animals of the experimental groups were inferior to control by $2.7-11.7 \%$ in terms of the eatability of coarse juicy feed.

Table 2. The proportion of feed consumed by experimental animals on nutrition.

\begin{tabular}{|c|c|c|c|c|c|c|c|c|}
\hline \multirow{3}{*}{ Stern } & \multicolumn{4}{|c|}{ Gobies } & \multicolumn{4}{|c|}{ Heifers } \\
\hline & \multicolumn{2}{|c|}{ Ia } & \multicolumn{2}{|c|}{$\mathrm{Ib}$} & \multicolumn{2}{|c|}{ IIa } & \multicolumn{2}{|c|}{$\mathrm{IIb}$} \\
\hline & feed units & $\%$ & feed units & $\%$ & feed units & $\%$ & feed units & $\%$ \\
\hline \multicolumn{9}{|c|}{ From birth to 8 months of age } \\
\hline Dairy & 152.0 & 17.5 & 88.6 & 13.9 & 142.3 & 17.4 & 88.6 & 13.9 \\
\hline Concentrates & 498.3 & 57.5 & 302.8 & 47.4 & 463.1 & 56.7 & 302.8 & 47.6 \\
\hline Rough, total & 43.6 & 5.0 & 51.0 & 8.0 & 43.6 & 5.3 & 51.0 & 8.0 \\
\hline $\begin{array}{l}\text { including } \\
\text { hay }\end{array}$ & 34.4 & 3.9 & 38.9 & 6.1 & 34.4 & 4.2 & 38.9 & 6.1 \\
\hline straw & 9.2 & 11 & 12.1 & 1.9 & 9.2 & 1.1 & 12.1 & 1.9 \\
\hline Juicy, total & 173.2 & 20.0 & 196.6 & 30.7 & 167.7 & 20.6 & 194.3 & 30.5 \\
\hline $\begin{array}{l}\text { including } \\
\text { corn silage }\end{array}$ & 62.6 & 7.2 & 66.9 & 10.5 & 61.6 & 7.5 & 68.5 & 10.8 \\
\hline Green feed & 110.6 & 12.8 & 129.7 & 20.2 & 106.1 & 13.1 & 125.8 & 19.7 \\
\hline Total & 867.1 & 100 & 639 & 100 & 816.7 & 100 & 636.7 & 100 \\
\hline \multicolumn{9}{|c|}{ From birth to 15 months of age } \\
\hline Dairy & 152.0 & 6.8 & 88.6 & 5.4 & 142.3 & 6.9 & 88.6 & 5.4 \\
\hline Concentrates & 1461.7 & 65.1 & 857.5 & 50.9 & 1282.7 & 62.3 & 825.7 & 50.2 \\
\hline Rough, total & 164.9 & 7.3 & 320.0 & 19.0 & 169.4 & 8.2 & 315.0 & 19.1 \\
\hline $\begin{array}{l}\text { including } \\
\text { hay }\end{array}$ & 152.2 & 6.8 & 178.5 & 10.6 & 156.8 & 7.6 & 176.8 & 10.7 \\
\hline straw & 12.7 & 0.5 & 141.5 & 8.4 & 12.6 & 0.6 & 138.2 & 8.4 \\
\hline Juicy, total & 468.3 & 20.8 & 418.5 & 24.7 & 465.5 & 22.6 & 416.4 & 25.3 \\
\hline $\begin{array}{l}\text { including } \\
\text { corn silage }\end{array}$ & 301.9 & 13.4 & 230.2 & 13.7 & 303.6 & 14.7 & 232.1 & 14.1 \\
\hline Green feed & 164.0 & 7.3 & 183.1 & 10.9 & 159.5 & 7.7 & 179.1 & 10.9 \\
\hline Total & 2246.9 & 100 & 1684.6 & 100 & 2059.9 & 100 & 1645.7 & 100 \\
\hline
\end{tabular}

Analysis of feeding showed that young experimental groups (Ia and IIa) consumed food in total nutrition in the diet structure about the same amount, and in comparison with analogues of control groups ( $\mathrm{Ib}$ and $\mathrm{IIb}$ ), these differences are significant in most cases $(\mathrm{P}>$ 0.95- 0.999). Thus, feeding of young animals with intensive cultivation was more abundant than with the traditional, adopted in most farms of the Rostov region.

Under such different growing conditions, we have established the features of the formation of reproductive organs in gobies and heifers. We conducted a study with intensive and traditional rearing of young animals in order to identify its early use for breeding purposes (table 3-6). 
Table 3. The growth dynamics of the reproductive apparatus in gobies, g.

\begin{tabular}{|c|c|c|c|c|c|c|}
\hline \multirow{3}{*}{ Mass indicators } & \multicolumn{6}{|c|}{ Group } \\
\hline & \multicolumn{3}{|c|}{ Ia, age, months } & \multicolumn{3}{|c|}{$\mathrm{Ib}$, age, months } \\
\hline & 8 & 12 & 15 & 8 & 12 & 15 \\
\hline Genital apparatus & 617 & 1275 & 1671 & 347 & 898 & 1446 \\
\hline Fat of the reproductive apparatus & - & - & 238 & - & - & 209 \\
\hline Scrotum & 130 & 240 & 413 & 65 & 170 & 363 \\
\hline Penis & 170 & 375 & 425 & 130 & 235 & 379 \\
\hline Prepuce & 35 & 45 & 57 & 20 & 40 & 46 \\
\hline Testis & 217 & 445 & 488 & 89 & 320 & 394 \\
\hline $\begin{array}{c}\text { including right } \\
\text { left }\end{array}$ & $\begin{array}{l}110 \\
107\end{array}$ & $\begin{array}{l}225 \\
220\end{array}$ & $\begin{array}{l}247 \\
241\end{array}$ & $\begin{array}{l}45 \\
44\end{array}$ & $\begin{array}{l}160 \\
160\end{array}$ & $\begin{array}{l}199 \\
195\end{array}$ \\
\hline Epididymis & 19 & 55 & 85 & 15 & 50 & 64 \\
\hline $\begin{array}{l}\text { including right } \\
\text { left }\end{array}$ & $\begin{array}{c}10 \\
9\end{array}$ & $\begin{array}{l}29 \\
26\end{array}$ & $\begin{array}{l}43 \\
42\end{array}$ & $\begin{array}{l}8 \\
7\end{array}$ & $\begin{array}{l}26 \\
24\end{array}$ & $\begin{array}{l}33 \\
31\end{array}$ \\
\hline Testicular serosa & 16 & 21 & 59 & 10 & 13 & 45 \\
\hline $\begin{array}{c}\text { including right } \\
\text { left }\end{array}$ & $\begin{array}{l}8 \\
8\end{array}$ & $\begin{array}{l}11 \\
10\end{array}$ & $\begin{array}{l}31 \\
28\end{array}$ & $\begin{array}{l}5 \\
5\end{array}$ & $\begin{array}{l}7 \\
6\end{array}$ & $\begin{array}{l}23 \\
22\end{array}$ \\
\hline Additional gonads & 29.4 & 87 & 137 & 17.6 & 65 & 128 \\
\hline $\begin{array}{c}\text { including vesicular } \\
\text { prostate } \\
\text { cooper }\end{array}$ & $\begin{array}{c}9 \\
15 \\
5.4\end{array}$ & $\begin{array}{l}40 \\
20 \\
27\end{array}$ & $\begin{array}{l}73 \\
27 \\
37\end{array}$ & $\begin{array}{c}4 \\
10 \\
3.6\end{array}$ & $\begin{array}{l}30 \\
15 \\
20\end{array}$ & $\begin{array}{l}68 \\
25 \\
35\end{array}$ \\
\hline Seed tube & 0.6 & 6.7 & 7.2 & 0.4 & 4.7 & 6.8 \\
\hline $\begin{array}{l}\text { The specific weight of the testes, } \\
\mathrm{g} / \mathrm{cm}^{3}\end{array}$ & 1.09 & 1.08 & 1.04 & 1.12 & 1.10 & 1.04 \\
\hline $\begin{array}{c}\text { including right } \\
\text { left }\end{array}$ & $\begin{array}{l}1.10 \\
1.07\end{array}$ & $\begin{array}{l}1.07 \\
1.08\end{array}$ & $\begin{array}{l}1.03 \\
1.04\end{array}$ & $\begin{array}{l}1.13 \\
1.10\end{array}$ & $\begin{array}{l}1.09 \\
1.10\end{array}$ & $\begin{array}{l}1.03 \\
1.04 \\
\end{array}$ \\
\hline
\end{tabular}

By weight of testes, bulls of group Ia at the age of 8 months exceeded peers of Ib by $128 \mathrm{~g}$ (2.4 times), by 12 - $125 \mathrm{~g}(39.1 \%)$ and by 15 - 94 (23.9). Moreover, in calves of group Ia from 8 to 12 months the mass of testes increased by $228 \mathrm{~g}$ ( 2 times), from 8 to 15 271 (2.3) and from 12 to 15 - by 43 (9.7\%); accordingly, in the bulls of the IB group - 231 (3.6), 305 (4.4) and 74 (23.1\%).

Table 4. The dynamics of the linear growth of the genital apparatus in gobies, $\mathrm{cm}$.

\begin{tabular}{|c|c|c|c|c|c|c|}
\hline \multirow{3}{*}{ Indicator } & \multicolumn{6}{|c|}{ Group } \\
\hline & \multicolumn{3}{|c|}{ Ia, age, months } & \multicolumn{3}{|c|}{ Ib, age, months } \\
\hline & 8 & 12 & 15 & 8 & 12 & 15 \\
\hline Penis: length & 73 & 80 & 84 & 62 & 72 & 76 \\
\hline diameter in the middle & 0.9 & 1.8 & 2.5 & 0.7 & 1.7 & 2.4 \\
\hline Prepuce: length & 21 & 25 & 27 & 15 & 20 & 22 \\
\hline cut width & 5 & 6 & 7 & 3 & 5 & 6 \\
\hline Appendage Length: right & 9.5 & 10.5 & 20.8 & 8.5 & 9.5 & 15.1 \\
\hline left & 9.5 & 10.5 & 20.8 & 8.5 & 9.5 & 15.0 \\
\hline Right testis: length & 10 & 10.7 & 12.3 & 7.5 & 10.2 & 11.2 \\
\hline $\begin{array}{l}\text { diameter in the } \\
\text { middle }\end{array}$ & 4.2 & 6.0 & 6.5 & 2.6 & 4.7 & 5.7 \\
\hline Left testis: length & & & & & & \\
\hline middle diameter in the & 4.1 & $\begin{array}{c}10.0 \\
5.8\end{array}$ & 6.2 & 2.5 & 4.7 & $\begin{array}{l}10.0 \\
5.6\end{array}$ \\
\hline Gland Length: vesicular & 9.5 & 12.3 & 12.6 & 7 & 10.5 & 10.6 \\
\hline prostate & 13 & 15.5 & 18 & 11.5 & 13 & 16 \\
\hline cooper & 2.5 & 3 & 4 & 2 & 2.8 & 3.8 \\
\hline Gland Width: vesicular & 2.5 & 4 & 5.1 & 2 & 3 & 3.7 \\
\hline prostate & 0.7 & 0.9 & 1.2 & 0.4 & 0.7 & 0.8 \\
\hline cooper & 1.3 & 1.9 & 2.2 & 1 & 1.2 & 1.9 \\
\hline
\end{tabular}


With age, the growth rate of the mass of testes decreases sharply, and already from 12 to 15 months of age it is 4.1-6.3 times lower than in the period from 8 to 12 months. But the growth of the testes at the age of 15 months does not end. In an adult bull, the mass of the testis reaches $300-350 \mathrm{~g}$, and the testes - 600-700 g, i.e. at the age of 15 months, bulls of the experimental group have $75.1 \%$ of the mass of adult bulls, and the control $-60.6 \%$. At the same time, the length of the testis in an adult bull is $12-14 \mathrm{~cm}$, and in bulls it is 15 months Ia groups $-12.2 \mathrm{~cm}, \mathrm{Ib}-11 \mathrm{~cm}$, i.e. the size of the length of the bulls have a smaller difference $-84.6-93.5 \%$.

When analyzing the growth of testes in all age periods, the right testis, as a rule, has a larger mass than the left. But the proportion of the left testis, starting at 12 months of age, is greater than the right. This is probably due to the fact that in the left testis there is still more connective tissue, and in the right - glandular. Therefore, it has a lower specific gravity.

Additional sex glands also in all age periods in bulls of intensive growth have better development, greater mass and linear dimensions. So, the mass of vesicular glands in gobies of group Ia at the age of 8 months exceeds that of peers Ib by $5 \mathrm{~g}$ (2.25 times), 12 $10(33.3 \%), 15-5(7.4 \%)$; respectively, prostate - by $5(1.5), 5(33.3), 2$ (8), Cooper - by 1.8 (1.5), 4 (35), 2 (5.7). The highest differences are observed at the 8 -month-old age of the gobies. Then they decrease by the age of 15 months become minimal (5.7-7.4\%). The mass of vesicular glands in the period from 8 to 12 months increased in gobies of the Ia group by $31 \mathrm{~g}$ or 4.4 times, and among peers Ib - by $26 \mathrm{~g}$ (7.5 times), and from 12 to 15 months - by $33(1.8)$ and $38(2,3)$; respectively, the mass of the prostate glands - $5 \mathrm{~g}(33.3 \%)$ and 5 (50), 7 (35) and 10 (66.7), cooper - 21.6 (5 times) and 16.4 (5.6 times) ), 10 (37\%) and 15 $(75 \%)$. In all analyzed periods, additional sex glands in gobies of the control group have a higher growth rate. However, complete compensation in the growth of the glands in them, in comparison with the experimental one at the age of 15 months, does not occur. A similar thing can be seen in their linear growth.

Regarding the completeness of the growth of the additional sex glands when comparing with the sizes of similar glands in adult bulls, we can state that in bulls of group Ib at the age of 15 months their growth is not yet completed, but for peers Ia - is completed. In adult gobies, the vesiculate glands have a length of 12, a width of 5 , a thickness of $3 \mathrm{~cm}$; the prostate gland consists of a weakly expressed body and a scattered part, each cooper gland (two of them) has the size of a large walnut (diameter 3-4 cm).

Gobies of group Ia at the age of 8 months by weight of the penis they exceeded peers $\mathrm{Ib}$ by $30.8 \%$, in 12 - by $59.6 \%$, in $15-12.1 \%$. At the same time, in bulls of intensive growth, the mass of the penis is from 8 to 12 months increased 2.2 times, length $-9.6 \%$, from 12 to 15 months -13.3 and 5\%, and from 8 to 15 months -2.5 times and $15.1 \%$; accordingly, the analogues of group I - 1.8 times and 16.1\%, 61.3 and 5.6\%, 2.9 times and 22.6\%. A larger increase in penis mass compared to its length occurs because in the analyzed period the penis thickness increases actively (in gobies of group I from 8 to 12 months, the diameter of the penis increases by 2 , from 8 to 15 months -2.8 times, from 12 to 15 months $-38.9 \%$, respectively, IB -2.4 and 3.4 times, $41.2 \%$. In adult bulls, the length of the penis reaches 100 , and during an erection $-150 \mathrm{~cm}$. In gobies intensive cultivation at 15 months. The length of the penis compared with adults is 84 , and the traditional $-76 \%$.

Analysis of the growth of testes and their appendages, vas deferens and accessory genital glands of the penis showed that with intensive growth, it occurs more intensively up to 8 months of age of gobies, and in traditional up to 15 months. At the same time, intensive cultivation contributes to the accelerated formation of the genitals and the earlier completion of their growth and development, which allows the use of gobies effectively at a young age, starting from 12 months of age.

Ovarian mass (table 5) in heifers of group IIa at the age of 8 months higher than IIb by $0.9 \mathrm{~g}(27.3 \%), 12-5.1 \mathrm{~g}$ (2.3 times more), $15-4.3 \mathrm{~g}(62.3 \%)$. At the same time, in all age 
periods, the right ovary is more developed than the left; in heifers of group IIa at 8 months the mass of the right ovary is $0.2 \mathrm{~g}(10 \%)$ more than the left, in 12 - by $2.1(60)$ and in $15-$ 0.8 (15.4); respectively, in heifers of group IIb - 0.3 (20), 0.2 (10.5) and 0.3 (9.1). In a cow, the ovaries are relatively small, weighing up to $14-19 \mathrm{~g}$. In heifers of group IIa, the mass of ovaries at the age of 15 months 2.8-7.8 g less than in adult cows, and in IIb, respectively, by 7.1-11.1 g. Heifers of group IIa for ovarian development, their weight is almost close to adult cows, and IIb in 2, 03-2.75 times the mass of the ovaries have less.

Table 5. The growth dynamics of the reproductive apparatus in heifers, $g$.

\begin{tabular}{|l|c|c|c|c|c|c|}
\hline \multirow{2}{*}{ Indicators } & \multicolumn{7}{|c|}{ Group } \\
\cline { 2 - 7 } & \multicolumn{3}{|c|}{ IIa, age, months } & \multicolumn{3}{c|}{ IIb, age, months } \\
\cline { 2 - 7 } & 8 & 12 & 15 & 8 & 12 & 15 \\
\hline Genital apparatus & 137.2 & 417.1 & 775.2 & 99.3 & 286.0 & 428.9 \\
\hline $\begin{array}{l}\text { Fat of the reproductive } \\
\text { apparatus }\end{array}$ & 130 & 170 & 620 & 78 & 110 & 310 \\
\hline Labia & 15 & 60 & 103 & 15 & 30 & 35 \\
\hline Vestibule of the vagina & 30 & 115 & 155 & 20 & 95 & 105 \\
\hline Vagina & 45 & 100 & 205 & 30 & 75 & 121 \\
\hline Cervix & 8 & 25 & 27 & 5 & 10 & 15 \\
\hline Uterine bodies & 5 & 10 & 43 & 5 & 10 & 38 \\
\hline Uterine horns & 25 & 90 & 220 & 16 & 55 & 100 \\
\hline Ovary & 4.2 & 9.1 & 11.2 & 3.3 & 4.0 & 6.9 \\
\hline including right & 2.2 & 5.6 & 6.0 & 1.8 & 2.1 & 3.6 \\
\hline left & 2.0 & 3.5 & 5.2 & 1.5 & 1.9 & 3.3 \\
\hline
\end{tabular}

In heifers IIa of the ovary group and in linear dimensions, length, width and thickness exceed IIb by 16.7-68.4\% (table 6).

Table 6. The dynamics of the linear growth of the reproductive apparatus in heifers, $\mathrm{cm}$.

\begin{tabular}{|c|c|c|c|c|c|c|}
\hline \multirow{3}{*}{ Indicator } & \multicolumn{6}{|c|}{ Group } \\
\hline & \multicolumn{3}{|c|}{ IIa, age, months } & \multicolumn{3}{|c|}{ IIa, age, months } \\
\hline & 8 & 12 & 15 & 8 & 12 & 15 \\
\hline Floor gap length & 7 & 10 & 11 & 6 & 7.5 & 8 \\
\hline $\begin{array}{l}\text { The vestibule of the vagina: } \\
\text { length } \\
\text { sectional width }\end{array}$ & $\begin{array}{l}8 \\
7\end{array}$ & $\begin{array}{c}12 \\
9\end{array}$ & $\begin{array}{l}13 \\
11\end{array}$ & $\begin{array}{l}8 \\
6\end{array}$ & $\begin{array}{c}10 \\
7\end{array}$ & $\begin{array}{l}12 \\
10\end{array}$ \\
\hline $\begin{array}{l}\text { Vagina: length } \\
\text { sectional width }\end{array}$ & $\begin{array}{l}16 \\
10\end{array}$ & $\begin{array}{l}22 \\
14\end{array}$ & $\begin{array}{l}25 \\
15 \\
\end{array}$ & $\begin{array}{c}14 \\
7\end{array}$ & $\begin{array}{l}17 \\
12 \\
\end{array}$ & $\begin{array}{l}19 \\
14 \\
\end{array}$ \\
\hline $\begin{array}{l}\text { Length: cervix } \\
\text { uterine bodies } \\
\text { uterine horns } \\
\end{array}$ & $\begin{array}{c}4 \\
4 \\
18 \\
\end{array}$ & $\begin{array}{c}4 \\
5 \\
30 \\
\end{array}$ & $\begin{array}{c}6 \\
8 \\
37 \\
\end{array}$ & \begin{tabular}{c|c}
3 \\
3 \\
13 \\
\end{tabular} & \begin{tabular}{c|}
3 \\
4 \\
19 \\
\end{tabular} & $\begin{array}{c}5 \\
6 \\
23 \\
\end{array}$ \\
\hline $\begin{array}{r}\text { Horn Diameter: cranially } \\
\text { the middle } \\
\text { caudally }\end{array}$ & $\begin{array}{l}- \\
- \\
-\end{array}$ & $\begin{array}{l}- \\
- \\
-\end{array}$ & $\begin{array}{l}1.8 \\
6.4 \\
3.3 \\
\end{array}$ & $\begin{array}{l}- \\
- \\
-\end{array}$ & $\begin{array}{l}- \\
- \\
-\end{array}$ & $\begin{array}{l}1.1 \\
3.1 \\
1.9\end{array}$ \\
\hline $\begin{array}{l}\text { Horn Length: } \\
\text { before horny separation } \\
\text { after separation }\end{array}$ & $\begin{array}{c}8 \\
10\end{array}$ & $\begin{array}{l}13 \\
17\end{array}$ & $\begin{array}{l}17 \\
20\end{array}$ & $\begin{array}{l}5 \\
8\end{array}$ & $\begin{array}{c}8 \\
11\end{array}$ & $\begin{array}{l}11 \\
13\end{array}$ \\
\hline $\begin{array}{r}\text { Sectional Width: cervix } \\
\text { uterine bodies }\end{array}$ & $\begin{array}{l}4 \\
4 \\
\end{array}$ & $\begin{array}{l}7 \\
5 \\
\end{array}$ & $\begin{array}{l}8 \\
7 \\
\end{array}$ & $\begin{array}{l}3 \\
3 \\
\end{array}$ & $\begin{array}{l}4 \\
5 \\
\end{array}$ & $\begin{array}{l}5 \\
7 \\
\end{array}$ \\
\hline $\begin{array}{l}\text { Horns: cranially } \\
\text { the middle } \\
\text { caudally }\end{array}$ & $\begin{array}{c}1.3 \\
4 \\
3 \\
\end{array}$ & $\begin{array}{l}3 \\
6 \\
5\end{array}$ & $\begin{array}{c}3 \\
11 \\
7 \\
\end{array}$ & $\begin{array}{l}1 \\
3 \\
2 \\
\end{array}$ & $\begin{array}{l}2 \\
4\end{array}$ & $\begin{array}{l}3 \\
7 \\
6 \\
\end{array}$ \\
\hline $\begin{array}{l}\text { Ovaries: length } \\
\text { width } \\
\text { thickness }\end{array}$ & $\begin{array}{l}2.2 \\
1.3 \\
0.7\end{array}$ & $\begin{array}{l}2.9 \\
1.7 \\
1.1\end{array}$ & $\begin{array}{l}2.9 \\
2.2 \\
1.6\end{array}$ & $\begin{array}{l}1.7 \\
1.2 \\
0.6\end{array}$ & $\begin{array}{l}1.8 \\
1.2 \\
0.7\end{array}$ & $\begin{array}{l}2.8 \\
2.0 \\
1.1\end{array}$ \\
\hline Oviduct Length & 16 & 22 & 24 & 13 & 15 & 19 \\
\hline
\end{tabular}

Note: the average development indicators are shown for the right and left uterine horns, ovaries and oviducts (diameter, length, width, thickness) 
Thus, according to the mass of ovaries, heifers of group IIb at the age of 15 months have lower indicators of ovarian development compared to analogues of IIa at the age of 12 months by $31.9 \%$. Similar is noted in linear dimensions. This suggests that intensive growth of heifers contributes to the growth of not only their live weight, but also the reproductive organs. The general development of the reproductive apparatus in them is better than in heifers of group IIb in all growing periods.

In adult cows, the length of the egg ducts is $21-28$, the inseparable caudal part of the uterus is $5-6$, the cervix is $-7-11$, the vagina is $22-28$, and the vestibule is $10-14 \mathrm{~cm}$. Heifers of intensive cultivation at the age of 15 months the size of the genitals is not much different and has almost the same development as adult cows. At the age of 12 months they had an increase in the mass of the reproductive apparatus compared with the age of 8 months 3.4 times, and heifers of group IIb only 2.9 times; respectively in 15 months compared with 8 months -5.7 and 4.3 times, and 15 months from 12 months -61.9 and $84.9 \%$. Although the growth rate of the genital organs from 12 to 15 months of age in heifers of group IIb is $23 \%$ higher than that of the experimental one, but this did not allow them to fully compensate for the lag in the growth of the genital apparatus. Heifers of group IIa in terms of mass of the sexual apparatus exceeded analogues of IIb at the age of 8 months by 38.2 , in 12 - by 45.8 , and in $15-57.4 \%$.

The good development of the genital organs of heifers of group IIa, and especially the ovaries, made it possible to carry out their fruitful insemination in the period from 13 to 14 months of age. For this, two calves from group Ia were selected at the age of 12-13 months, who inseminated 20 heifers for a month by manual mating. During a rectal examination, they turned out to be all pregnant and in due time, without complications, became hotels, gave normal viable offspring. Calving calves aged 22-23 months during 1 lactation they were in no way inferior in milk production to heifers inseminated at the age of 24-28 months and calving at 33-37 months.

\section{Conclusion}

Thus, the intensive cultivation of red steppe young growth positively affects the formation of genital organs and allows the use of bulls to reproduce when they reach 12, and heifers 13-14 months of age. After calving without complications, the heifers showed high milk productivity (for at least $5800 \mathrm{~kg}$ of milk after 300 days of lactation) in a timely manner, during the first two months they came to hunting and inseminated fruitfully. This made it possible to introduce young stock into the turnover of the herd for more than a year compared with the traditional cultivation technology, thereby increasing the breeding efficiency and significantly reducing feed consumption for growing young stock.

\section{References}

1. P. Zelenkov, A. Baranikov, A. Zelenkov, Cattle breeding, textbook (Rostov-on-Don, 2006)

2. A. Zelenkov, PhD Thesis (2004)

3. A. Zelenkov, A. Ermakov, G. Zelenkova et all, E3S Web of Conferences 135, 01088 (2019)

4. A. Zelenkov, A. Ermakov, G. Zelenkova et all, IOP Conf. Series: Earth and Environmental Science 403, 012020 (2019) 
5. P. Zelenkov, A. Zelenkov, A. Zelenkov, A multi-thematic online electronic scientific journal of the Kuban State Agrarian University 77, 600 (2012)

6. P. Zelenkov, A. Zelenkov, G. Zelenkova, Veterinarnaya patologiya 3-4(49-50), 15 (2014)

7. P. Zelenkov, Izvestia Orenburg State Agrarian University 1(5), 124 (2005)

8. Richard P. Kipling, Helen E. Taft, David R. Chadwick, David Styles, Jon Moorby, Environmental Science \& Policy, 92, 107-115 (2019)

9. Richard P.Kiplinga, Environmental Science \& Policy, Volume 101, Pages 232-244 (2019) https://doi.org/10.1016/j.envsci.2019.08.015 